\title{
FORMATION OF INVESTMENT ONTOLOGICAL PROVISION OF AGRICULTURAL ENTERPRISES IN THE RADIOACTIVE CONTAMINATION
}

\author{
Vitalina KALENSKA ${ }^{1}$ \\ Zhytomyr National Agroecological University, Ukraine
}

\begin{abstract}
The paper aims at clarifying the ontological system formation features of the investment support of agricultural enterprises on the radiation-contaminated area. The objects of the research are the agricultural enterprises on the radiation-contaminated area. The article highlights the concept of investment support of agricultural enterprises which revealed the main principles of the investment activity organization; equality of all investors; equal rights for all investors; investment security; noninterference of the subjects to the investment process in the investment activity, subject to compliance with applicable law; independence in the selection of criteria for investment activities; observation of the rights and interests of the investment process participants when they conduct investment activities. Methods. The study is based on scientific principles, means of scientific knowledge the use of which ensured the reliability of the results obtained and resolution of the goals and objectives. Findings. The author has identified the features of the investment attractiveness of the agricultural enterprises located on the radiation-contaminated areas of Ukraine that resulted in the finding that the agricultural enterprises in Ukraine subjected to radioactive contamination are particularly problematic in terms of the investment development, which include: Volyn, Zhytomyr, Kyiv, Rivne and Chernihiv regions. It is in these regions that the agribusinesses face considerable problems, since the investors, as usual, are afraid to invest due to numerous risks - not only environmental, but also economic and social. Practical significance. The investment support ontological system of the agricultural enterprises on the radiation-contaminated area is formed according to the following principles: clarity, consistency, scalability, least coding effect and least ontological commitments. It is also found that the ontology should be subject to a specific set of operations, which include: addition of new subjects, changing subjects, removal of the subject and search. Conditions of successful investment at the macrolevel are determined by the following factors: stability and predictability of the political system; condition of the national economy (inflation level, GDP growth rates, production of major products, budget deficits, etc.) and prospects for its development; level of development of the state regulation system of innovation and investment development of territories and sectors; tax policy of the state; level of socio-economic development of the country, people's living standards; level of investment risk and uncertainty in the environment. The macrolevel includes international and national levels of the ontology which are most favourable for investment support of the enterprises operating on the radiation-contaminated areas. Value/ uniqueness. Having studied the investment support system ontology of the agricultural enterprises located on the radiation-contaminated area we made certain generalizations that lie in the fact that the investment attractiveness at the macrolevel is determined by a number of conditions created by a state for all economic entities, including foreign investors, to make a profitable investment in order to develop the national economy. The author selected the parameters of investment support system of the agricultural enterprises located on the radiation-contaminated area and suggested an ontology equation for the system of investment support of agricultural enterprises on the radiation-contaminated area.
\end{abstract}

Key words: investment support, investment attractiveness, ontology, radioactive contamination, agricultural enterprises.

JEL Classification: D21, E22, F14

\footnotetext{
Corresponding author:

${ }^{1}$ Zhytomyr National Agroecological University.

E-mail: vitalina_k17@mail.ru
} 


\section{Introduction}

Stable and effective development of regions must be provided by outstripping growth rates of workforce productivity and, therefore, sufficient volume of investments. In the current context one of the most pressing challenges is the search of new approaches and methods in regard to the growth of investments in the regions' economy that allows providing economic development of the territories. Regions that are considered to be polluted are under difficult challenge. Agricultural enterprises that are located on the polluted territory cannot realize manufacture efficiently as their products are not in demand. It should be noted that foreign investors who value ecological properties of goods are not highly motivated to provide enterprises located in the polluted areas with financial resources.

Moreover, negative ecological and economic status of such regions and agricultural enterprises that are located on their territory influences the investment activities in this sector of economy. This preconditions the dynamic solutions of the existing production and socio-economic problems in the abovementioned regions.

Promotion of investment prospects and inflow of additional investments into the economy of the polluted regions are still limited due to the persistent deficits of financial resources on the part of manufacturers and low paying capacity of the population, violation of provisions in agrarian business, weak participation of the state in promotion of the investments. By implication most of the Ukrainian regions polluted with radiation are considered as subsidized territories: this does not allow facilitating any investments for long-term projects, especially for middle and small business patterns. Therefore, Ukraine cannot count upon the prospective development of investment field without active support of the state and review of the investment strategic planning on the basis of promotion of investment prospects in the polluted regions.

In this regard, topicality and significance of theoretical, methodological, scientific and practical grounds for research are of immediate interest today, including realization of investment prospects strategies for agricultural enterprises that are located on the polluted territories on the basis of identifying the priority guidelines of regions' development, possibilities of coordination and enhancement of production and distribution activities, more effective use of state forms of support for the purpose of achieving economic security and regions' growth as well as social welfare. Thus, the choice of the article's subject was determined by the great interest to the search of new approaches and methods in regard to the formation of ontological system for providing agricultural enterprises located on the polluted territories with investments.

\section{The notion of investment provision of the agricultural enterprises}

Under general approach to the solution of the most important state problems in food security sector and stable social, and economic development of its regions, in particular those that are considered to be polluted,under executive decision-making process about allocation and efficiency enhancement of investmentson all hierarchical levels, it is essential to realize their nature, interrelations between investment variforms and processes as well as stable formation of investments prospects in various state regions with developed agricultural production. Thus, it is important to analyze the notion of investments and investment provision of the agricultural enterprises located in the polluted area.

The essence and content of the "investment" category is understood differently within various branches of economic science and in practical business activity. According to the macroeconomic approach investments are identified as a part of GDP, which is not consumed in the running period, and is considered as addition to capital. In other words, investments are the element total expenditure, connected with production facilities renovation, development of manufacturing and social infrastructure, inventory changes, etc. In microeconomics, in particular within the production theory approach, investments are identified as the formation process of new capital aimed at expanding reproduction of capital assets and building-up of human capital assets (Verzylyn, 2007).

V. Fedorenko points out that the underlying motive of investments is the realization of profit in the form of additions to capital. Research results of the investment theory confirm the interrelation between investment activity and additions to capital. The highest efficiency is achieved by allocation of innovative projects (Fedorenko, 2004).

$\mathrm{H}$. Tsado offers fundamental composition of investment according to the areas of usage: production expansion andmodernization; creation of production infrastructure; creation of inventory and stocks; creation of social infrastructure; personnel's professional training and skills maintenance; science and scientific services. The crucial role for investing in innovations is played by real investments market, taking into account the fact that real investments are aimed at increasing production capital, in other words, livestock (Tsado, 2011).

According to A. Peresada, innovation investments are investments in new developments. He considers that under stable economic growth all investments must be recognized at the same time as innovations. In a down economy investment can be used to support operating technically underdevelopedproduction facilities (Peresada, 2001).

T. Leybyert in her scientific works considers investment process as a large-scale cumulative action 
of search of the best investment solutions, connected with investor's participation in investment property management with the aim of receivinginvestment income in certain investment environment. The main tool is investment activity, which is the activity of investment subject, who organizes, realizes and manages the investment process. The scientist believes that investment activity should be considered as the systematized body of rules and principles that identify the form and content of economic relations during the investment process with the aim of providing the existence of the object in future (Leybyert, 2009).

M. Denysenko and A. Hrechan consider investment provision system of innovative activity cast of economic relations that are formed in respect of search, involvement and efficient use of investments as wellas organization and management principles, methods and forms of their influence on life-sustaining activity of investments. They emphasize that investing in innovative activity is aimed at resources' provision of positive structural innovative shifts in economy (Denysenko, Hrechan, Haman, 2008).

T. Tovt interprets the definition of the "investment provisions system of enterprises' innovative activity" asaset of economic relations that are formed in respect of search that are formed in respect of search, involvement and use of investment resources required for investing in various directions of enterprises' innovative activities with account of the existing internal chambers of these resources and possibilities to involve them from external sources (Tovt, 2012).

Taking into account the essence and content of the "investment prospects" category, it is possible to distinguish the following key principles of investment activity organization:

- voluntary investing;

- equality of all the investment process participants;

- equality of all the investors;

- investments security;

- non-interference of investment process parties into the investment activity under the condition of adherence to the law;

- independence in choosing the criteria for investment activity execution;

- adherence to the rights and interests of all the investment process participants during the execution of investment activity;

Among the key sources of the investments involvement to the machine builder are the following:

a) internal funds:

- state public funding;

- credit funds;

- revenues from public property privatization;

- equity capital.

b) externalfunds:

- foreign investors' resources;

- external credits;
- loans;

- otherexternalinvestmentsources.

\section{The peculiarities of investment prospects of the agricultural enterprises located in the polluted territories of Ukraine}

Current status of agricultural enterprises' investment activity depends significantly on the role and place of this industry sector in the agrarian business. Principally, it is subject to the nature of the economic relations between agricultural sector and other sectors of AIC. Moreover, it is formed under the influence of various natural environment and climatic, economic, financial, social and other peculiarities of the agricultural sector (Peresada, 2001).

Among the most problematicinvestment development agricultural enterprises are those, which are located in the polluted territories of Ukraine, including Volyn Oblast, Zhytomyr Oblast, Kyiv Oblast, Rivne Oblast and Chernihiv Oblast. AIC enterprises are facing the greatest problems in these regions as the investors are afraid to invest in them due to the numerous ecological, economic and social risks.

Insufficient volumes of funds available for investment caused the material and production resources depletion, reduction of their cost effectiveness, low level of production concentration and specialization, poor development of agricultural market's infrastructure. From our point of view, sufficient amount of capital resources guarantees renovation and improvement of agricultural production's material and technical basis, enhancement of its efficiency, promotion of agricultural sector's competitive abilities as a whole. Material and resources' provision of agricultural production, its effective development under the conditions of transitive economy depend directly on the volumes, structure and investment directions including construction expenses, maintenance of production space, machinery and equipment, introduction of new technologies, provision of sufficient level of paying capacity, growth of financial support. Moreover, insufficient financial package of the agricultural sector has a negative influence on investment activity of the agricultural enterprises located in the polluted territories. This preconditions equipment operation, load increase of old-fashioned equipment per unit, which in its turn weakens the effectiveness of agricultural enterprises' production; reduction of major construction, growth of unemployment in rural localities (Buslenko, 2013).

Taking into account the development of the country, internal funds (profit accumulation in the form of amortization fund; profits that are used for renovation and production expansion) are the key source of capital investments. However, in the current situation internal capital investment funds of the agricultural enterprises in Ukraine are rather depleted. It is preconditioned by 
the low level of production cost effectiveness and fixed assets value (in particular, amortization funds).

In the countries with market economy capital maintenance problems and introduction of advanced technology are resolved due to the flexible system of amortization funds' functioning. Amortization as the main source of investment of the Ukrainian agricultural enterprises falls back every year. The main reasons for that are considerable underrun of fixed assets revaluation rates from actual costs during escalation (Savits'ka, 2010).

Investment environment deterioration in agricultural sector was caused by the following factors (Ratoshnyuk, 2013):

1) reduction of financial resources flow-in (shortfall of sales) as a consequence of the low effectual demand on food products;

2) additional income reductions of home producers for unreasonably high fraction of imported food products on the Ukrainian internal market (shrinkage of market outlets);

3) carrying-out of cardinal reconstruction of the entire fiscal relations system within short time frames, refusal of state backing of agricultural sector without any adequate compensation of food producer's material losses;

4) maintenance of the industrial sector monopolized structure of home agricultural plant and lack of market mechanisms for price relations between agricultural, processing, trading and purchasing, and resource-saving enterprises. As a consequence, price parity has increased and financial cost proportions of interindustry exchange have deteriorated, misbalance between income and expenditure has been formed;

5) incompletion of land reforms processes and institutional transformations in agricultural sector;

The significant role in formation of the investment provision system of development of the agricultural enterprises located in the polluted territories is played by factors which influence the investment prospects. Such factors include the groups, which determine the level of investment prospects of the territories for investors (Butko, 2005):

- factors, which influence the level of regions' investment potential (natural and geographic, labour, industrial, innovative, institutional, infrastructural, financial, and consumption potentials);

- factors, which determine the level of uncommercial investment risks (legislative, political, social, economic, ecological and criminal risks);

- investment activity (concertation and distribution of investment assets, promotion, implementation of new capacities, development of direct and portfolio investments).

It should be noted that investments in agricultural production are used for (Andriychuk, 2004): substitution of old-fashioned and worn-out equipment; introduction of new technology and employment of modern machinery, and equipment; expansion of agricultural production; development of new production activities.

Among the key strategic aims of investment provision of the agriculture development on a long-term horizon with account of defined goal are the following (Lupenko, 2012):

- formation of funding sources for a full supply of agricultural sector development needs with investment resources;

- development of internal investment agricultural capacities of producers to the level that provides optimum compromise between in-house and thirdparty investment funding sources;

- expansion of financing capacity for the road industry development in rural localities as one of the key factors of investment prospects promotion of agriculture and its effectiveness.

Taking into account the above mentioned purpose the ontological system of investment provision of the agricultural enterprises located in the polluted territories should be formed.

\section{Formation of the ontological system of investment provision of the agricultural enterprises located in the polluted area}

Before analyzing the formation process of the ontological system of investment provision of the agricultural enterprises located in the polluted area, it is essential to give definition to the notion of "ontology".

The word "ontology" has two meanings: discipline of philosophy, which deals with the most common characteristic features of objective reality; artifact, structure that describes the meaning of elements in a system. Informally, ontology is perceived as description of world view on a certain subject area of interests. This description includes terms and rules of terms' usage that limit these meanings within certain field. Formally, ontology is a system, which consists of a range of notions and statements about the latter, on the basis of which the classes, relations, functions and theories are described (Hayna, 2014).

Ontology is a certain structure that describes the meaning of the elements belonging to a certain system; a set of notions, including the most general and concrete ones, which provide a full range of objects and relations, events and processes as well as attribute values and relations, which are defined if needed in time and space. Ontology of investment provision describes investment activity, its constituents, which influence directly the involvement of investments in agricultural enterprises.

Every ontology has its vocabulary and thesaurus. The vocabulary of investment provision ontology includes the range of definitions that characterize the agricultural enterprises' activity, describing their peculiarities and features. Nowadays there are many ontologies, however, most of them cannot be used in the sphere of investment 
provision of the agricultural enterprises located in the polluted area as they have a range of specific notions (Hayna, 2014).

In the simplest sense, ontology includes the following stages of formation (Vitushko, 2011):

- allocation of concepts - basic notions of a certain subject field;

- interaction of basic notions;

- comparison of a constructed ontology with existing types (correlation with other fields of knowledge).

There are numerous approaches and methodologies to the creation of ontology. Most of them are based on the principles offered by T. Gruber (Gruber, 1993):

1. Clarity - an ontology should effectively communicate the intended meaning of defined terms (the latter must not cause the user feel cognitive dissonance);

2. Coherence - an ontology should logically consistent;

3. Extendibility - an ontology should have space for expansion;

4. Minimal encoding bias - the conceptualization the created ontology based on should be specified at the knowledge level without depending on a particular symbol-level encoding;

5. Minimal ontological commitment - an ontology should consist of the most essential hypotheses about world's modulation.

The thesaurus of the investment provision system of the agricultural enterprises located on the polluted territories is identified as connectivity between objects of a certain subject field.

Relations between objects can be of three types: synonymous, hierarchical and associative. Ontological system of investment provision of the agricultural enterprises located on the polluted territories includes the class of objects and the class of parameters.

The general view of ontology can be depicted by means of the following formula (Hayna, 2014):

$\mathrm{O}=\{\mathrm{P}, \mathrm{C}, \mathrm{A}\}-$ hard ontologies;

$\mathrm{O}=\{\mathrm{P}, \mathrm{C}\}-$ soft ontologies;

where: $\mathrm{O}$ is an ontology (description of living environment); $\mathrm{P}$ isa set of subject field concepts (parameters of investment environment); $\mathrm{C}$ is a set of relations between the latter, $\mathrm{A}$ is an axiom set (laws and rules that describe laws and principles of concepts' existence). A certain set of actions should be done within ontology. Among them are:

1. Addition of new subjects. In order to add them one should point out the basic indicator for a subject, which is connected with properties of the subject.

2. Changing of subjects. There are certain parameters for changing a subject.

3. Extraction of subjects. In case of adding and changing of subjects one should point out new and changed parameters. In order to extract a subject, it is essential to know the place the latter takes in general hierarchy, the way the hierarchy of subjects changes and the properties of asubject after extraction as well as to determine the relations between this subject and the others, and how its extraction can influence the child subjects.

\section{Search.}

The systematization of the parameters of the investment provision system of the agricultural enterprises located on the polluted territories can be seen on the table 1 .

Thus, $\mathrm{S}$ in the table represents the investment provision system of the agricultural enterprises located

Table 1

The investment provision system parameters of the agricultural enterprises located on the polluted territories

\begin{tabular}{|c|c|c|}
\hline № & Level & Parameters \\
\hline 1 & International & $\begin{array}{l}\text { SM1 - investments of international financial organizations } \\
\text { SM2 - investments of external investors } \\
\text { SM3 - assistance of the international economic and diplomatic institutions } \\
\text { SM4 - countries that promote investments in the agricultural enterprises located on the polluted territories }\end{array}$ \\
\hline 2 & National & $\begin{array}{l}\text { SN1 - state investments in the polluted territories } \\
\text { SN2 - investment prospects of agricultural businesses } \\
\text { SN3 - occupational level in the polluted territories } \\
\text { SN4 - supply of labour } \\
\text { SN5 - favourable investment environment in the country } \\
\text { SN6 - availability of sufficient financial and legal framework in the country }\end{array}$ \\
\hline 3 & Regional & $\begin{array}{l}\text { SR1 - availability of investment activity promotion in the region's territory } \\
\text { SR2 - availability of material and technical base } \\
\text { SR3 - availability of sufficient number of personnel } \\
\text { SR4 - favourable investment environment in the region's territory } \\
\text { SR5 - existence of enterprises that are in need of investments }\end{array}$ \\
\hline 4 & Level of enterprise & $\begin{array}{l}\text { SP1 - labour, innovative, personnel, production potential } \\
\text { SP2 - basic material and technical base } \\
\text { SP3 - availability of fixed assets } \\
\text { SP4 - type and form of enterprise property } \\
\text { SP5 - enterprise size } \\
\text { SP6 - readiness for investments involvement }\end{array}$ \\
\hline
\end{tabular}


on the polluted territories, $\mathrm{M}, \mathrm{N}, \mathrm{R}$, and $\mathrm{P}$ are the parameters of the international, national, regional levels and the level of enterprise.

All the parameters given in the table are used for description of ontology according to the definite principles:

- the notions of ontology are coined on the basis of certain subject field parameters of living environment;

- multi-level hierarchical composition of the notions' terminological system;

- principles of the notions' description and interrelations between them.

According to the abovementioned scheme, the ontology equation for the investment provision of the agricultural enterprises located on the polluted territories appears as follows:

$$
\mathrm{O}=\left\{\mathrm{P}_{\mathrm{M}, \mathrm{N}, \mathrm{R}, \mathrm{P}}, \mathrm{C}, \mathrm{A}\right\} \text {, }
$$

where $\mathrm{O}$ is an ontology of the investment provision system of the agricultural enterprises located on the polluted territories; P, M,N,R, are a set of levels of the investment provision system of the agricultural enterprises located on the polluted territories; $\mathrm{C}$ is a set of relations between them; $\mathrm{A}$ is an axiom set (laws and rules that describe laws and principles of $\mathrm{M}, \mathrm{N}, \mathrm{R}$ and $\mathrm{P}$ levels' existence).

\section{Conclusions}

Thus, having conducted the research of ontology of the investment provision system of the agricultural enterprises located on the polluted territories, it is possible to conclude that investment prospects on the macroeconomic level are determined by a range of conditions, which are created by state for all subjects of economy management including foreign investors for profitable investment with the aim of national economy development. The conditions of the successful investing on the macro-level are determined by the following factors: stability and foreseeability of the political system; status of the national economy (inflation rate, GDP growth rate, production volumes of the most important product types, budget deficit, etc.) and prospects of its development; maturity level of the governmental regulation system of the territories and branches' innovative and investmentdriven development; state tax policy; level of social and economic development of the country, quality of life; level of investment risks and uncertainties in business environment. Macro-level includes international and national levels of ontology, which are the most favorable for investment provision of enterprises located on the polluted territories.

\section{References}

Andriychuk, V. H. (2004). Ekonomika ahrarnykh pidpryyemstv - Kyiv: KNEU, 624.

Buslenko, B. V. (2013). Potreba v zaluchenni investytsiy v ahropromyslovyy kompleks Ukrayiny. Retrieved from: http://nauka.kushnir.mk.ua/?p=71179

Butko, M. (2005). Suchasna problematyka otsinky investytsiynoyi pryvablyvosti rehionu, Moskva, 30-35.

Denysenko, M. P., Hrechan, A. P., Haman M. V. (2008). Provaydynh innovatsiy, Kyiv, 448.

Endovytskoho, D. A. (2010). Analyz ynvestytsyonnoy pryvlekatelnosty orhanyzatsyy - Moskva, 376.

Fedorenko, V. H. (2004). Investoznavstvo, Kyiv, 480.

Gruber, T. R. (1993). A translation approach to portable ontologies - Knowledge Acquisition, 199-220.

Hayna, H. A. (2014). Vykorystannya ontolohichnoho pidkhodu dlya opysu obyektiv zhytlovoho seredovyshcha Upravlinnya rozvytkom skladnykh system, 107-111.

Leybyert, T. B. (2009). Metodolohiya formuvannya systemy investytsiynoho zabezpechennya innovatsiynykh protsesiv na pidpryyemstvakh. avtoref. dys. dokt. nauk, 40 p. Retrieved from: http://www.dissers.ru/ avtoreferatidissertatsii-ekonomika/a605.php

Lupenko Yu.O. (2012). Stratehichni napryamy rozvytku silskoho hospodarstva Ukrayiny na period do 2020 roku. Kyiv, 218.

Peresada, A. A. (2001). Investuvannya: Navch.-metod. posibnyk: KNEU, 251.

Ratoshnyuk, T. M. (2013). Investytsiyna pryvablyvist' ahrarnoyi sfery - Visnyk Sumskoho natsionalnoho ahrarnoho universytetu. Finansy i kredyt, 88-93.

Savitska, S. I. (2010) Investytsiynykh rozvytok silskoho hospodarstva v suchasnykh umovakh - Visnyk Khmelnytskoho natsionalnoho universytetu, p. 16-19.

Tovt, T. Y. (2012). Investytsiyne zabezpechennya innovatsiynoyi diyalnosti mashynobudivnykh pidpryyemstv. avtoreferat dys. kand. ekon. nauk: 08.00.04 Lviv, 20.

Tsado, H. V. (2011) Sutnist ta znachennya innovatsiyno-investytsiynykh protsesiv $\mathrm{v}$ systemi rehionalnoho rozvytku - Innovatsiyna ekonomika, 154-160.

Verzylyn, V. A. (2007). Ynvestytsyonnaya pryvlekatelnost ahropromishlennoho kompleksa rehyona - Voronezh, $422 \mathrm{p}$.

Vitushko, A. (2011). Ontolohiyi yak zasib orhanizatsiyi veb-portaliv analitychnykh struktur komunikatsiyi Naukovi pratsi Natsionalnoyi biblioteky Ukrayiny im. V.I. Vernadskoho, 309-315. 
Vol. 2, No. 4, 2016

\section{ВиталИна КАЛЕНСКАЯ}

\section{ФОРМИРОВАНИЕ ОНТОЛОГИЧЕСКОЙ СИСТЕМЫ ИНВЕСТИЦИОННОГО ОБЕСПЕЧЕНИЯ СЕЛЬСКОХОЗЯЙСТВЕННЫХ ПРЕДПРИЯТИЙ НА ТЕРРИТОРИИ РАДИАЦИОННОГО} ЗАГРЯЗНЕНИЯ

Аннотация. Целью работы является выяснение особенностей формирования онтологической системы инвестиционного обеспечения сельскохозяйственных предприятий на территории радиационного загрязнения. Объектами исследования выступают сельскохозяйственные предприятия на территории радиационного загрязнения. В статье выделены понятия инвестиционного обеспечения сельскохозяйственных предприятий, что обнаружило основные принципы организации инвестиционной деятельности; равноправие участников инвестиционного процесса; равноправие всех инвесторов; защищенность инвестиций; невмешательства субъектов инвестиционного процесса в инвестиционную деятельность, при условии соблюдения действующего законодательства; независимость при выборе критериев для осуществления инвестиционной деятельности; соблюдение прав и интересов участников инвестиционного процесса при осуществлении ими инвестиционной деятельности. Методика. Исследование основано на научных принципах, средствах научного познания, применение которых обеспечило достоверность полученных результатов и решения поставленных целей и задач. Результаты. Автором выяснены особенности инвестиционной привлекательности сельскохозяйственных предприятий радиационно загрязненных территорий Украины, в результате чего установлено, что особенно проблемными в инвестиционном развитии сельскохозяйственных предприятий являются территории Украины, подвергшихся радиационному загрязнению, к которым относим: Волынскую, Житомирскую, Киевскую, Ровенскую, и Черниговскую области. Именно в этих регионах предприятия АПК сталкиваются с немалыми проблемами, поскольку обычно инвесторы боятся вкладывать свои средства в связи с многочисленными рисками, не только экологическими, но и экономическими и социальными. Практическое значение. Осуществлено формирование онтологической системы инвестиционного обеспечения сельскохозяйственных предприятий на территории радиационного загрязнения согласно следующих принципов: ясность, согласованность, расширяемость, минимум влияния кодирования и минимум онтологических обязательств. Также выяснено, что над онтологией нужно делать определенный набор операций, к которым относятся: добавление новых субъектов, изменение субъектов, изъятие субъекта и поиск. Условия успешных капиталовложений на макроуровне определяются следующими факторами: стабильностью и предсказуемостью политической системы; состоянием национальной экономики (уровень инфляции, темпы роста ВВП, объемы производства важнейших видов продукции, дефицит бюджета и др.) и перспективами ее развития; уровнем развития системы государственного регулирования инновационноинвестиционного развития территорий и отраслей; налоговой политикой государства; уровнем социальноэкономического развития страны, жизненным уровнем населения; уровнем инвестиционных рисков и неопределенности среды функционирования. До макроуровня относим международный и национальный уровни онтологии, которые наиболее благоприятны для инвестиционного обеспечения предприятий, действующих на радиационно загрязненных территориях. Значение/оригинальность. Проведя исследование онтологии системы инвестиционного обеспечения сельскохозяйственных предприятий на территории радиационного загрязнения нами осуществлены определенные обобщения, которые заключаются в том, что инвестиционная привлекательность на макроэкономическом уровне определяется рядом условий, которые создает государство для всех субъектов хозяйствования, в том числе для иностранных инвесторов, для выгодного капиталовложения с целью развития национальной экономики. Автор выбрал параметры системы инвестиционного обеспечения сельскохозяйственных предприятий на территории радиационного загрязнения и предложил уравнение онтологии для системы инвестиционного обеспечения сельскохозяйственных предприятий на территории радиационного загрязнения. 